\title{
Мировой опыт создания пивоваренных сортов ячменя на основе беспроантоцианидиновых мутантов
}

\author{
О.Ю. Шоева (iD凶
}

\begin{abstract}
Аннотация: Актуальным направлением отечественной селекции ячменя в настоящее время является получение пивоваренных сортов. Поскольку именно от качества используемого сырья в первую очередь зависит качество готового продукта, пивоваренная промышленность предъявляет высокие требования к таким сортам. Одной из главных качественных характеристик пива является его стойкость при хранении, которая определяется временем помутнения пива и влияет, таким образом, на срок годности. Различают биологическое помутнение, образующееся в результате размножения микроорганизмов, и небиологическое (коллоидное), в основе которого лежит взаимодействие белков и полифенолов пива с образованием стабильных нерастворимых комплексов. Традиционная селекция пивоваренных сортов направлена на снижение содержания белка, однако, как показал мировой опыт, высококачественные сорта можно также получить с помощью снижения содержания в зерне полифенольных соединений. В обзоре суммированы данные о синтезе главных полифенольных компонентов коллоидного помутнения пива - проантоцианидинов, которые легли в основу получения пивоваренных беспроантоцианидиновых сортов ячменя. Реализованный в мировой практике опыт может быть полезен при разработке отечественных селекционных программ, направленных на создание высококачественных пивоваренных сортов ячменя.
\end{abstract}

Ключевые слова: конденсированные танины; индуцированный мутагенез; пиво; флавоноиды; полифенолы.

Благодарности: Знакомство автора с коллекцией безантоциановых/беспроантоцианидиновых мутантов ячменя в Лундском университете (Лунд, Швеция) поддержано грантом Swedish Institute Visby Programme No. 25896/2018. Публикация подготовлена в рамках работы по проекту Минобрнауки России «Курчатовский центр геномных исследований мирового уровня» № 075-152019-1662.

Для цитирования: Шоева О.Ю. Мировой опыт создания пивоваренных сортов ячменя на основе беспроантоцианидиновых мутантов. Письма в Вавиловский журнал генетики и селекции. 2021;7(1):23-33. DOI 10.18699/LettersVJ2021-7-04

\section{The world experience of malting barley cultivars breeding based on proanthocyanidin-free mutants}

\section{O.Yu. Shoeva $\mathrm{iD} \otimes$}

Abstract: Currently, the breeding of the barley malting cultivars is a priority direction of the domestic breeding programs. Since the quality of the raw materials used determine primarily the quality of the beer, the brewing industry makes high demands on such cultivars. One of the main quality characteristics of beer is its haze stability, which determines shelf life of beer. There are two types of turbidity: biological one is resulted from the propagation of microorganisms, and nonbiological (colloidal) one is based on the interaction of proteins and polyphenols of beer with the formation of stable insoluble complexes. Traditional breeding of malting cultivars is aimed at reducing the protein content, however, high-quality cultivars can also be obtained by reducing the content of polyphenolic compounds in grain as well. Here, the data on studies of the main polyphenolic components of colloidal haze of beer proanthocyanidins is summarized. These data represented the basis for breeding of malting proanthocyanidin-free cultivars. The world experience implemented in practice can be useful for the development of domestic breeding programs aimed at creating high-quality malting barley cultivars.

Key words: condense tannins; induced mutagenesis; beer; flavonoids; polyphenols.

For citation: Shoeva O.Yu. The world experience of malting barley cultivars breeding based on proanthocyanidin-free mutants. Pisma v Vavilovskii Zhurnal Genetiki i Selektsii = Letters to Vavilov Journal of Genetics and Breeding. 2021;7(1):23-33. DOI 10.18699/LettersVJ2021-7-04 (in Russian)

Федеральный исследовательский центр Институт цитологии и генетики Сибирского отделения Российской академии наук, Новосибирск, Россия Курчатовский геномный центр Федерального исследовательского центра Институт цитологии и генетики Сибирского отделения Российской академии наук, Новосибирск, Россия

Institute of Cytology and Genetics of Siberian Branch of the Russian Academy of Sciences, Novosibirsk, Russia

Kurchatov Genomic Center of the Institute of Cytology and Genetics of Siberian Branch of the Russian Academy of Sciences, Novosibirsk, Russia

هolesya_ter@bionet.nsc.ru

(C) Шоева О.Ю., 2021 
Пиво - слабоалкогольный напиток, получаемый спиртовым брожением солодового сусла с помощью пивных дрожжей, обычно с добавлением хмеля. Сырьем для приготовления пива служит ячменный солод. Его получают из пивоваренных сортов ячменя в процессе солодоращения проращивания зерна в контролируемых условиях с целью накопления в них ферментов, способных расщеплять глюканы, крахмалы и белки зерна на необходимые для спиртового брожения компоненты (Главачек, Лхотский, 1977).

К пивоваренным сортам предъявляют ряд требований, обусловленных как технологическим процессом производства солода, так и качественными характеристиками готового продукта. В нашей стране существует многоступенчатая система оценки сортов пивоваренного ячменя, при успешном прохождении которой сорта могут быть рекомендованы для внесения в Государственный реестр селекционных достижений, допущенных к использованию на территории РФ (Кобелев и др., 2015). Система оценки сортов включает полевые испытания на госсортоучастках, где оценивают их урожайность, устойчивость к болезням, полегаемость и другие сельскохозяйственные признаки, и лабораторные исследования, в ходе которых определяют качество зерна (по таким показателям, как крупность и натура, способность прорастать на 5-й день, пленчатость, содержание белка и крахмала, массовая доля экстракта в сухом веществе ячменя) и качество приготовленного из него солода (содержание белка, некрахмальных полисахаридов, число Кольбаха, продолжительность осахаривания, массовая доля экстракта в сухом веществе солода) (Кобелев и др., 2015).

Одной из важных характеристик пивоваренных сортов является содержание белка. Хотя белок служит источником усвояемых дрожжами азотистых соединений и определяет пенную стойкость пива, его содержание в зерне пивоваренного назначения не должно превышать $11.5 \%$. Более высокое содержание белка снижает экстрактивность (сумму растворенных веществ, которые при затирании переходят в сусло), затрудняет фильтрацию и вызывает коллоидное помутнение пива (Steiner et al., 2011). Помутнение является главной причиной пониженной стойкости пива, которая определяется временем от розлива пива до образования заметного помутнения. Различают биологическое помутнение, образующееся в результате размножения дрожжей или других микроорганизмов, и небиологическое (коллоидное), возникающее при нарушении коллоидного равновесия (Главачек, Лхотский, 1977). Коллоидное помутнение пива наступает с понижением температуры и исчезает при нагревании. При длительном хранении и воздействии кислорода воздуха, света, ионов металлов холодное помутнение превращается в необратимое, неисчезающее. Если проблема биологического помутнения на сегодняшний день успешно решена путем использования пастеризации и обеспложивающей фильтрации, то вопрос коллоидного помутнения является более сложным и, несмотря на пристальное внимание ученых, до конца не решен. Сегодня известно, что основу коллоидного помутнения составляют белковая и полифенольная фракции, а также в незначительных количествах другие вещества, главным образом сахариды и некоторые катионы (Steiner et al., 2010). Традиционная селекция пивоваренных сортов ячменя направлена на снижение содержания белковой фракции, однако, как показал мировой опыт, снижение полифенольной фракции также может быть эффективным способом повышения качества и продолжительности хранения готового пива (von Wettstein, 2007).

Благодаря шведской программе индуцированного мутагенеза в 70-90-х гг. получена уникальная коллекция мутантов ячменя, насчитывающая более 700 индивидуальных линий, у которых был нарушен синтез флавоноидных соединений. С помощью теста на аллелизм идентифицированы тридцать групп комплементации, мутации в которых приводили к нарушению синтеза антоцианов и/или проантоцианидинов на различных стадиях их синтеза (Jende-Strid, 1993). Наибольший интерес для пивоваренной промышленности представляли мутанты, у которых был нарушен синтез проантоцианидинов. Эти полимерные соединения образуются в оболочке зерна ячменя и сначала из солода, а потом из сусла попадают в готовое пиво, где во время охлаждения способны связываться с белками и приводить к его помутнению. В ходе селекционных программ в ряде европейских стран на основе некоторых мутантов созданы и зарегистрированы высокоурожайные пивоваренные сорта (von Wettstein, 2007).

В представленном обзоре отражены результаты многолетних исследований флавоноидного метаболизма у ячменя с использованием коллекции индуцированных мутантов, которые легли в основу селекционных программ, направленных на преодоление проблемы коллоидного помутнения пива. Представленные данные могут быть полезны при разработке отечественных селекционных программ по созданию высококачественных сортов ячменя пивоваренного назначения.

\section{Фенольные соединения пива и их роль в коллоидном помутнении}

Фенольные соединения являются важными компонентами пива, определяющими его вкус, цвет, коллоидную стабильность (Wannenmacher et al., 2018). К этим соединениям относятся простые фенолы, содержащие одну фенольную группу, и полифенолы, имеющие в своем строении несколько фенольных групп. Источниками фенольных соединений пива является сырье, из которого его готовят - ячмень и хмель. В зерне ячменя фенольные соединения представлены свободными и связанными фенольными кислотами, лигнанами, фениламидами (конъюгатами фенольных кислот с аминами) и флавоноидами, в том числе их полимерной группой - проантоцианидинами. Наибольшее содержание фенольных кислот обнаружено во внешних слоях зерновок ячменя (чешуях, перикарпе, оболочке зерна, клетках алейрона), где они присутствуют в основном в связанном с полисахаридами клеточных стенок виде. При этом в алейроновом слое зерновок преобладает транс-феруловая кислота, а в цветковых чешуях - -кумаровая (Nordkvist et al., 1984).

Хмель добавляют в пиво для придания горечи, приятного хмелевого аромата и повышения его микробиологической стабильности. Ценными ингредиентами хмеля являются твердые и мягкие смолы, полифенолы и эфирные масла. Как и у ячменя, фенольные соединения хмеля пред- 

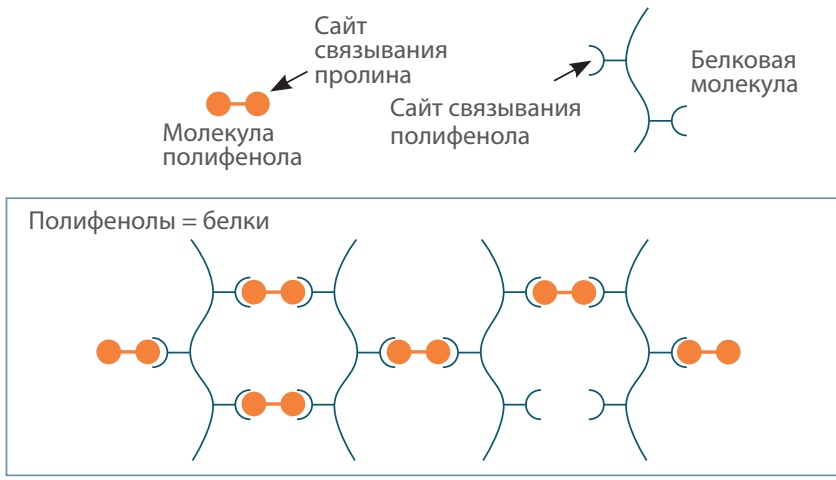

Полифенолы > белки
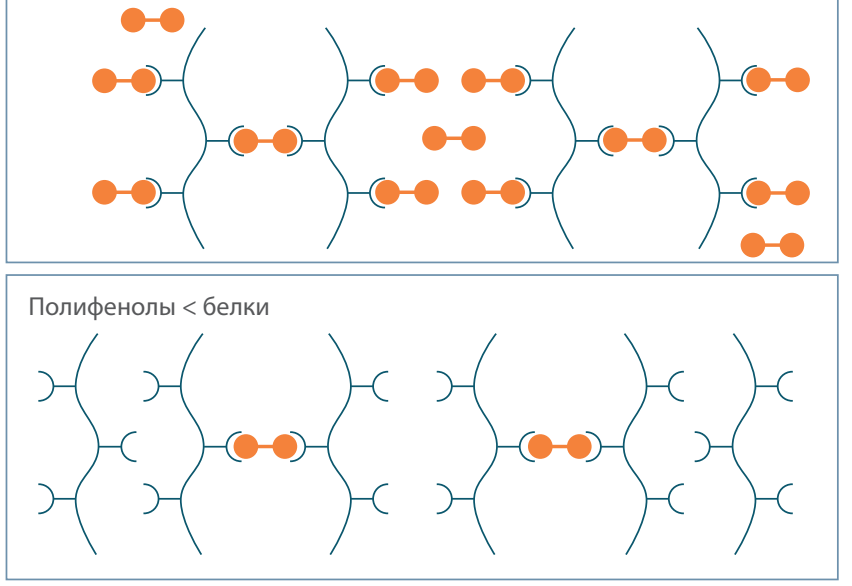

Рис. 1. Коллоидное помутнение пива связано со взаимодействием богатых пролином белков пива и полифенольных соединений (Siebert, Lynn, 1998)

Fig. 1. Beer haze formation is caused by interaction proline-rich proteins and polyphenolic compounds (Siebert, Lynn, 1998)

ставлены фенольными кислотами, моно- и олигомерными флавоноидными соединениями: флавонолами, гликозидами флавонолов (кемпферол, кверцетин), проантоцианидинами (Wannenmacher et al., 2018). Среди наиболее изученных фенольных соединений хмеля особое место занимает ксантогумол, обладающий высокой биологической активностью. Это соединение образуется из тетрагидроксихалкона с помощью реакции пренилирования и метилирования (Venturelli et al., 2016). Хотя ячменный солод содержит значительно меньше фенольных соединений на единицу массы, чем хмель, именно фенольные соединения ячменного происхождения составляют 70-80\% всех фенольных соединений пива, вызывающих его коллоидное помутнение (Wannenmacher et al., 2018). Исследования компонентного состава помутнения показали, что активными в отношении помутнения белками являются богатые пролином запасные белки зерна ячменя - гордеины. При этом содержание пролина определяет степень помутнения: чем больше пролина, тем выше помутнение (Asano et al., 1982). Поиск фенольного компонента помутнения проведен с помощью модельной системы, в которой к активным в отношении образования помутнения белкам добавляли различные фенольные соединения. Так, установлено, что фенольные кислоты и большинство мономерных полифенолов ячменя и хмеля не участвуют в формировании помутнения (Asano et al., 1984). Небольшое помутнение пива обнаружено при добавлении в систему мономеров проантоцианидинов - эпикатехина и катехина. Димеры (процианидин В3 и продельфинидин В3) и полимеры проантоцианидинов показали наибольшую активность в формировании помутнения, при этом чем выше степень полимеризации, тем большее помутнение наблюдалось (Asano et al., 1984; Siebert, Lynn, 1998). Исследование динамики помутнения в зависимости от соотношения в буферном растворе белков и полифенолов позволило предложить модель взаимодействия компонентов, согласно которой полифенольные соединения с как минимум двумя рядом расположенными гидроксильными группами связываются с пролинами разных белковых молекул с формированием сложных комплексов (рис. 1). При этом наиболее эффективное связывание наблюдается при почти равном соотношении полифенолов и связывающих их белков (Siebert, 1999).

Для решения проблемы коллоидного помутнения пива используют различные технологические приемы: хранение пива при низких температурах, добавление протеолитических ферментов или адсорбентов, специфических к активным в отношении образования помутнения белкам (силикагель) либо полифенолам (поливинилпирролидон). 


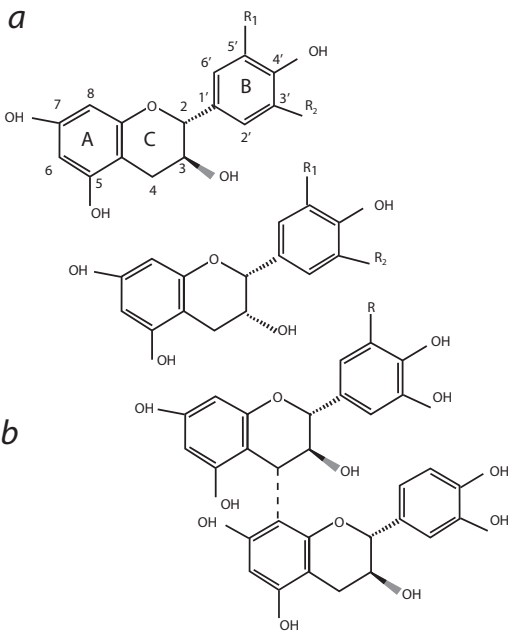

$$
\begin{aligned}
& \mathrm{R}_{1}=\mathrm{H}, \mathrm{R}_{2}=\mathrm{H}:(+) \text {-афзелехин } \\
& \mathrm{R}_{1}=\mathrm{H}, \mathrm{R}_{2}=\mathrm{OH}:(+) \text {-катехин } \\
& \mathrm{R}_{1}=\mathrm{OH}, \mathrm{R}_{2}=\mathrm{OH}:(+) \text {-галлокатехин } \\
& \mathrm{R}_{1}=\mathrm{H}, \mathrm{R}_{2}=\mathrm{H}:(-) \text {-эпиафзелехин } \\
& \mathrm{R}_{1}=\mathrm{H}, \mathrm{R}_{2}=\mathrm{OH}:(-) \text {-эпикатехин } \\
& \mathrm{R}_{1}=\mathrm{OH}, \mathrm{R}_{2}=\mathrm{OH}:(-) \text {-эпигаллокатехин }
\end{aligned}
$$

$\mathrm{R}=\mathrm{H}$ : процианидин димер B3 $\mathrm{R}=\mathrm{OH}$ : продельфинидин димер В3

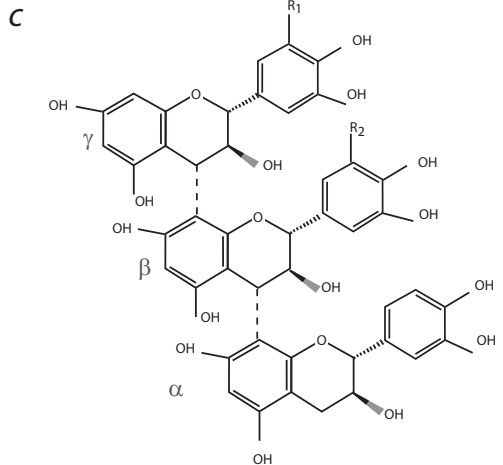

$$
\begin{gathered}
\mathrm{R}_{1}=\mathrm{H}, \mathrm{R}_{2}=\mathrm{H} \text { : процианидин тример С2 } \\
\alpha \mathrm{K}_{8-4,} \beta \mathrm{K}_{8-4,} \gamma \mathrm{K} \\
\mathrm{R}_{1}=\mathrm{OH}, \mathrm{R}_{2}=\mathrm{H}: \text { продельфинидин тример C2 } \\
\alpha \mathrm{K}_{8-4,} \beta \mathrm{K}_{8-4}, \gamma \Gamma \mathrm{K}
\end{gathered}
$$$$
\alpha \mathrm{K}_{8-4,} \beta \Gamma \mathrm{K}_{8-4}, \gamma \Gamma \mathrm{K}
$$

Рис. 2. Структура флаван-3-олов, являющихся мономерными единицами проантоцианидинов (a), проантоцианидиновые димеры (b) и тримеры (с) зерна ячменя (Jende-Strid, 1993)

K - катехин, ГК - галлокатехин; (+) и (-) соответствуют транс- и цис-изоформам

Fig. 2. Structure of barley flavan-3-ols, that represent monomeric units of proanthocyanidins $(a)$, dimeric $(b)$ and trimeric $(c)$ proanthocyanidins in barley grain (Jende-Strid, 1993)

$\mathrm{K}$ - catechin, ГK - gallocatechin; (+) and (-) correspond to trans- and cis-isoforms

Перечисленные приемы помогают снизить концентрацию белков, полифенолов или обоих этих компонентов (Siebert, Lynn, 1998). Однако предложенные техники действуют достаточно неспецифически и помимо нежелательных компонентов удаляют из состава пива важные для его качества компоненты. В 70-х гг. прошлого века в качестве альтернативы технологической обработке готового пива для повышения его стабильности при хранении предложен и реализован нетрадиционный подход: снижение фракции проантоцианидинов в зерне пивоваренного назначения за счет введения в селекцию практики мутантных аллелей генов биосинтеза проантоцианидинов (von Wettstein, 2007). Это стало возможным благодаря полученным в Швеции индуцированным мутантам ячменя с нарушенным синтезом антоцианов и/или проантоцианидинов.

\section{Проантоцианидины ячменя и их синтез}

Проантоцианидины представляют собой олиго- и полимерные производные флаван-3-олов, относящихся к классу флавоноидов. Все флавоноиды имеют С15-углеродный скелет, состоящий из двух бензольных колец, А и В, соединенных С3-фрагментом, который с атомом кислорода образует С-кольцо (рис. 2). Степень окисления С-кольца определяет класс флавоноидного соединения (Бриттон, 1986). Флаван3-олы являются наиболее восстановленной группой флавоноидов. У этих соединений гидроксильная группа в СЗ- и фенил в С2-положениях могут быть расположены как в цисориентации (эпикатехины), так и транс-ориентации (катехины) относительно плоскости пирана.

Структура проантоцианидина зависит от типа мономеров (в том числе их пространственной организации), паттерна гидроксилирования и этерификации их гидроксильных групп, степени полимеризации и типа связи между мономерами. Выделяют три класса проантоцианидинов: процианидины, продельфинидины и пропеларгонидины. Процианидинами называют олигомеры с гидроксильными группами в 3'- и 4'-положениях В-кольца, продельфинидины и пропеларгонидины являются смешанными олигомерами, в которых по крайней мере один из мономеров содержит гидроксильные группы в 3'-, 4'-, 5'-положениях и 4'-положении соответственно (Dixon et al., 2005). Мономерные единицы могут быть соединены тремя типами связи. Наиболее распространенной является В-связь С $4 \beta \rightarrow$ С 8 a. Связь, при которой мономерные единицы соединены одновременно связями С $2 \beta \rightarrow$ O7a и C4 $\beta \rightarrow$ C8a, называется А-связью; она является более жесткой по сравнению с В-связью. Наконец, выделяют С-связь, в которой мономеры соединены через C4 $\rightarrow$ C6 атомы углерода (Aron, Kennedy, 2008).

У ячменя проантоцианидины образованы (+)-катехиновыми (К) и (+)-галлокатехиновыми (ГК) мономерными единицами. В зерне ячменя выявлены два димерных и четыре тримерных проантоцианидина, среди которых наиболее 


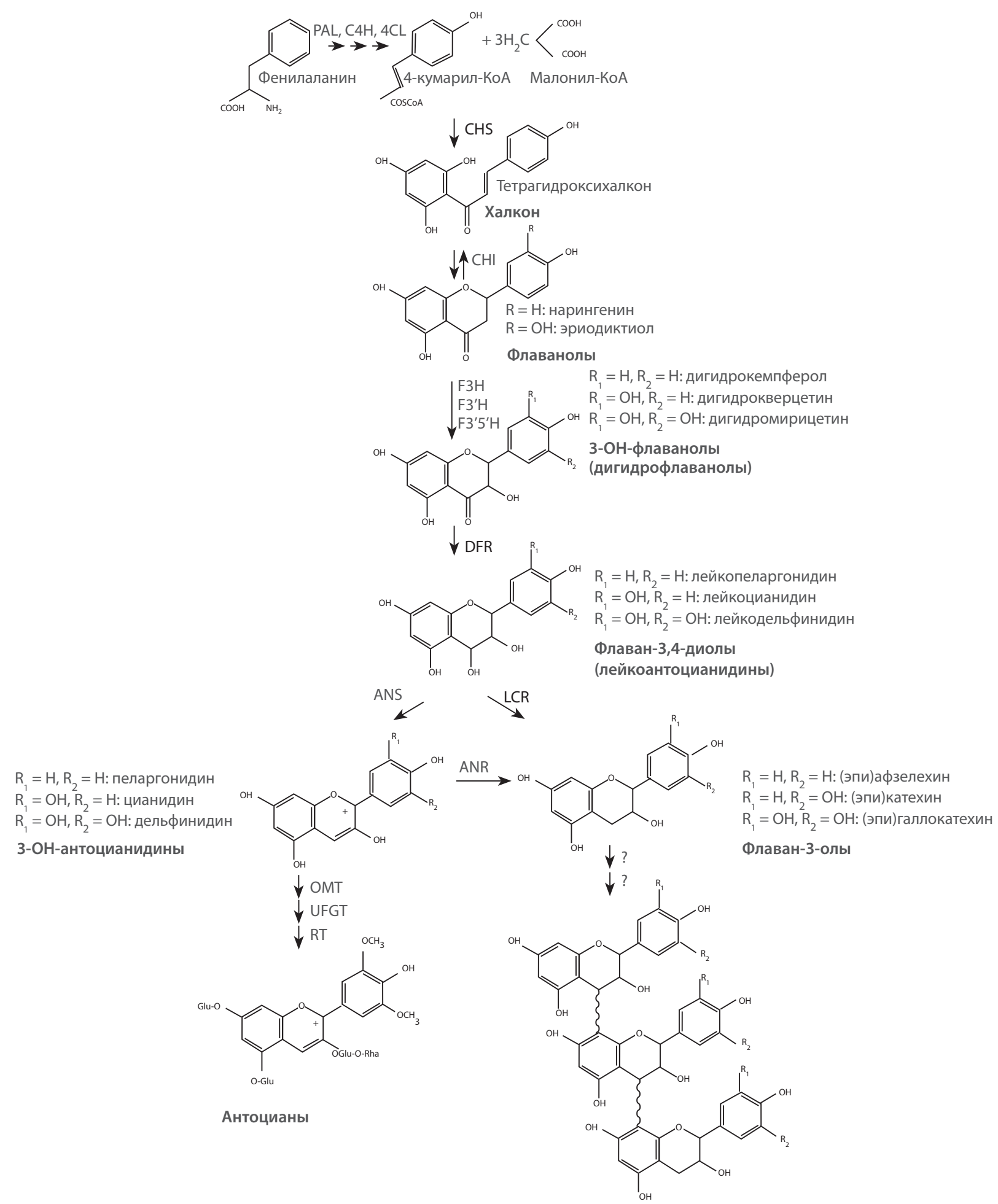

Проантоцианиды

Рис. 3. Схема синтеза проантоцианидинов у растений (Jende-Strid, 1993; Winkel-Shirley, 2001)

4CL - 4-кумарат-КоА-лигаза; ANR - антоцианидинредуктаза; ANS - антоцианидинсинтаза; CHI - халконфлаванонизомераза; C4H - циннамат-4гидроксилаза; CHS - халконсинтаза; DFR - дигидрофлавонол-4-редуктаза; F3Н - флаванон-3-гидроксилаза; F3'H - флавоноид-3'-гидроксилаза; F3'5'Hфлавоноид-3',5'-гидроксилаза;UFGT-UDP-флавоноид-3-О-гликозилтрансфераза; LCR-лейкоантоцианидинредуктаза;ОМT-O-метилтрансфераза; PAL - фенилаланинаммиаклиаза; RT - рамнозилтрансфераза

Fig. 3. Schematic representation of the flavonoid biosynthesis pathway (Jende-Strid, 1993; Winkel-Shirley, 2001)

$4 \mathrm{CL}$ - 4-coumarate-CoA ligase; ANR - anthocyanidin reductase; ANS - anthocyanidin synthase; $\mathrm{CHI}$ - chalcone-flavanone isomerase; $\mathrm{C} 4 \mathrm{H}$ - cinnamate-4hydroxylase; CHS - chalcone synthase; DFR - dihydroflavonol 4-reductase; $\mathrm{F3H}$ - flavanone 3-hydroxylase; F3'H - flavonoid 3'-hydroxylase; F3'5' H - flavonoid 3',5'-hydroxylase; UFGT - UDP-glucose flavonoid 3-O-glucosyltransferase; LCR - leucoanthocyanidin reductase; PAL - phenylalanine ammonia-lyase; RT - rhamnosyltransferase 
представленными являются процианидин В3, продельфинидин В3, процианидин С2 $\left(a \mathrm{~K}_{8-4}, \beta \mathrm{K}_{8-4}, \gamma \mathrm{K}\right)$ и продельфинидин C2 ( $\left.a \mathrm{~K}_{8-4}, \beta \mathrm{K}_{8-4}, \gamma \Gamma \mathrm{K}\right)$ (Zimmermann, Galensa, 2007) (см. рис. 2).

Биосинтез всех флавоноидных соединений, включая проантоцианидины, начинается с фенилаланина (рис. 3). Фенилаланинаммиаклиаза (PAL), циннамат-4-гидроксилаза $(\mathrm{C} 4 \mathrm{H})$, 4-кумарат-КоА-лигаза $(4 \mathrm{CL})$, действуя поочередно, преобразуют фенилаланин в 4-кумарил-КоА. Последующая конденсация одной молекулы 4-кумарил-КоА и трех молекул малонил-КоА с помощью халконсинтазы (CHS) приводит к образованию тетрагидроксихалкона, который является предшественниками различных классов флавоноидных соединений. Под действием халконфлаванонизомеразы (CHI) тетрагидроксихалкон превращается в нарингенин. Последний является субстратом для ферментов, осуществляющих реакции гидроксилирования С-кольца В положение С3 либо В-кольца в положение С3'. Так, нарингенин с помощью фермента флаванон-3-гидроксилазы (F3H) преобразуется в дигидрокемпферол (DHK), а с помощью флавоноид-3'-гидроксилазы (F3'H) - в эриодиктиол. Гидроксилирование дигидрокемпферола с помощью F3'H или флавоноид-3,'5'-гидроксилазы (F3'5'H) приводит к образованию дигидрокверцетина (DHQ) или дигидромирицетина (DHM) соответственно. Полученные дигидрофлавонолы восстанавливаются дигидрофлавонол-4-редуктазой (DFR) до соответствующих флаван-3,4-диолов - лейкопеларгонидина, лейкоцианидина и лейкодельфинидина. Флаван-3,4диолы являются субстратами для двух ферментов - антоцианидинсинтазы (ANS) и лейкоантоцианидинредуктазы (LCR). ANS преобразует флаван-3,4-диолы в соответствующие 3-ОН-антоцианидины - пеларгонидин, цианидин и дельфинидин, являясь специфическим для антоциановой ветви биосинтеза ферментом. В последующих этапах биосинтеза антоцианов участвуют ферменты, относящиеся к классам метил- (МT), гликозил- (GT) и ацилтрансфераз (AT).

LCR катализирует специфическое для синтеза проантоцианидинов NADPH-зависимое восстановление флаван3,4-диолов до соответствующих 2,3-транс-флаван-3-олов, например (+)-катехина. У некоторых видов растений, например арабидопсиса и люцерны, проантоцианидины образованы цис-изоформами флаван-3-олов с участием антоцианидинредуктазы (ANR). Хотя активность фермента выявлена в развивающемся зерне ячменя, цис-изоформы флаван-3олов в зерне не обнаружены (Dixon et al., 2005). Наименее исследованными на сегодняшний день остаются последние этапы сборки мономерных флаван-3-олов в проантоцианидиновые олигомеры (Dixon, Sarnala, 2020).

\section{Коллекция безантоциановых/}

\section{беспроантоцианидиновых мутантов ячменя}

Первоначальная коллекция мутантов ячменя с нарушенным синтезом антоцианов, легко выявляемых визуально, получена на селекционной станции в Свалёве (Швеция) в ходе программы радиационного мутагенеза, инициированной в 1928 г. Германом Нильсоном-Эле и Оке Густафссоном (Lundqvist, 2014). Коллекция насчитывала 52 мутанта, у 41 из которых наблюдалось снижение содержания антоцианов в вегетативных органах по сравнению с исходными сортами, а у 11 - увеличение (Jende-Strid, 1978). С помощью качественных реакций на проантоцианидины, проводимых посредством замачивания зерна в растворах ванилина с $\mathrm{HCl}$ (Aastrup et al., 1984) или щелочи (Lamkin, Miller, 1980), под действием которых эти соединения приобретают коричневую окраску, выявлен первый мутант ant13.13, у которого отсутствие антоцианов в вегетативных органах сопровождалось отсутствием проантоцианидинов в зерне (JendeStrid, 1978). Именно с него фактически началась программа селекции беспроантоцианидиновых сортов, инициированная пивоваренной компанией Carlsberg (Дания). Позже с введением в практику химического мутагенеза азида натрия получено еще 560 мутантов на более чем 80 сортах и селекционных линиях ячменя из Европы, Америки и Японии. В общей сложности на наличие проантоцианидинов В зерне протестировано более 8.5 млн растений $\mathrm{M2}$, полученных после обработки мутагеном. Частота мутаций, обусловливающих нарушение синтеза этих соединений, оценена в 0.003\% (von Wettsein, 2007). Позднее разработан метод прижизненного тестирования проантоцианидинов в зерне ячменя, заключающийся в локальном нарушении целостности оболочек зерна и обработки места среза реагентами для выявления проантоцианидинов (Kristensen, Aastrup, 1986). Благодаря разработанной методике идентифицированы дополнительные 107 мутантов, у которых был нарушен только синтез проантоцианидинов, тогда как мутации не влияли на синтез антоцианов (von Wettsein, 2007).

В настоящий момент коллекция, объединяющая мутантов с нарушенным синтезом, антоцианов и проантоцианидинов насчитывает 766 индивидуальных мутантов, которые с помощью тестов на аллелизм были сгруппированы в 30 групп комплементации, или локусов (табл. 1). Все идентифицированные локусы можно разделить на четыре группы. В первую группу входят локусы, мутации в которых приводят к одновременному отсутствию антоцианов в вегетативных органах и проантоцианидинов в зерне. К таким локусам относятся Ant13, Ant17, Ant18, Ant21, Ant22 и Ant30. В следующую группу объединены локусы, мутации в которых затрагивают синтез антоцианов, но не проантоцианидинов. К ним относятся локусы Ant1, Ant2, Ant5 и Ant20. Мутации в локусе Ant20 приводят к усилению синтеза антоцианов, тогда как мутации в остальных локусах этой группы - к его подавлению. В третью группу входят локусы, мутации в которых подавляют синтез проантоцианидинов и не затрагивают синтез других групп флавоноидных соединений. В эту группу объединены локусы Ant19, Ant25-29. В последнюю, четвертую, группу отнесены локусы, мутации в которых снижают количество антоциановых пигментов в вегетативных органах. К ним относятся Ant3, Ant4, Ant6-12, Ant14-16, Ant23 и Ant24. Эти локусы рассматривают как модуляторы биосинтеза антоцианов (Jende-Strid, 1993).

Исследование биохимического состава зерна ячменя и активности ферментов биосинтеза флавоноидов позволило определить функции ряда Ant-локусов, для некоторых из них выделены гены. Установлено, что Ant18 кодирует DFR (Kristiansen, Rohde, 1991), Ant30 - CHI (Druka et al., 2003), Ant17 и Ant22 - субъединицы F3H (Jende-Strid, 1993; Himi, 
Таблица 1. Коллекция беспроантоцианидиновых/безантоциановых мутантов ячменя. Указана хромосомная локализация локуса; присутствие антоцианов в вегетативных органах и проантоцианидинов в зерне согласно данным B. Jende-Strid $(1978,1993) ;$ для каждого локуса представлен номер паспорта в Barley Genetics Stock (BGS, https://www.nordgen.org/bgs/ index.php), содержащий его описание

Table 1. Collection of proanthocyanidin-free/anthocyanin-free barley mutants. The chromosomal localization of the locus and the presence of anthocyanins in vegetative organs and proanthocyanidins in grain according to B. Jende-Strid $(1978,1993)$ are indicated; a Barley Genetics Stock passport number (BGS, https://www.nordgen.org/bgs/index.php) for each locus containing its description is listed

$\begin{array}{llll}\text { № Локус } & \begin{array}{l}\text { Хромосомная } \\ \text { локализация }\end{array} & \begin{array}{l}\text { Антоцианы } \\ \text { в вегетативных } \\ \text { органах }\end{array}\end{array} \quad \begin{aligned} & \text { Проантоциани- } \\ & \text { диныв верне }\end{aligned} \quad$ BGS $\quad$ Молекулярные функции Источник литературы

Мутанты с нарушенным синтезом антоцианов и проантоцианидинов

\begin{tabular}{|c|c|c|c|c|c|c|c|}
\hline 1 & Ant13 & $6 \mathrm{HL}$ & - & - & 598 & & \\
\hline 2 & Ant17 & $3 \mathrm{HS}$ & - & - & 599 & $\begin{array}{l}\text { Флаванон-3- } \\
\text { гидроксилаза }\end{array}$ & Himi, Taketa, 2015 \\
\hline 3 & Ant18 & $3 \mathrm{H}$ & - & - & 600 & $\begin{array}{l}\text { Дигидрофлаванол-4- } \\
\text { редуктаза }\end{array}$ & Kristiansen, Rohde, 1991 \\
\hline 4 & Ant21 & $6 \mathrm{H}$ & - & - & 603 & & \\
\hline 5 & Ant22 & $2 \mathrm{HL}$ & - & - & 604 & $\begin{array}{l}\text { Флаванон-3- } \\
\text { гидроксилаза }\end{array}$ & Meldgaard, 1992 \\
\hline 6 & Ant30 & $5 \mathrm{HL}$ & - & - & 610 & $\begin{array}{l}\text { Халконфлаванони- } \\
\text { зомераза }\end{array}$ & Druka et al., 2003 \\
\hline
\end{tabular}

Мутанты с нарушенным синтезом антоцианов, но не проантоцианидинов

\begin{tabular}{|c|c|c|c|c|c|c|c|}
\hline 7 & Ant1 & 7HS & - & + & 33 & TФ R2R3-MYB & $\begin{array}{l}\text { Himi, Taketa, 2015b; } \\
\text { Shoeva et al., 2015; } \\
\text { Zakhrabekova et al., } 2015\end{array}$ \\
\hline 8 & Ant2 & $2 \mathrm{HL}$ & - & + & 80 & TФ bHLH & $\begin{array}{l}\text { Cockram et al., 2010; } \\
\text { Shoeva et al., } 2016\end{array}$ \\
\hline 9 & Ant5 & $2 \mathrm{HL}$ или $5 \mathrm{HL}$ & - & + & 596 & & \\
\hline 10 & Ant20 & & $\uparrow$ & + & 602 & & \\
\hline \multicolumn{8}{|c|}{ Мутанты с нарушенным синтезом проантоцианидинов, но не антоцианов } \\
\hline 11 & Ant19 & & + & - & 601 & $\begin{array}{l}\text { Лейкоантоцианидин- } \\
\text { редуктаза }\end{array}$ & Jende-Strid, 1993 \\
\hline 12 & Ant25 & & $\downarrow$ & - & 605 & & \\
\hline 13 & Ant26 & & + & - & 606 & & \\
\hline 14 & Ant27 & & + & - & 607 & & \\
\hline 15 & Ant28 & $3 \mathrm{HL}$ & + & - & 608 & TФ R2R3-MYB & Himi et al., 2012 \\
\hline 16 & Ant29 & & + & $\downarrow$ & 609 & & \\
\hline
\end{tabular}

Мутанты с количественными изменениями в содержании антоцианов/проантоцианидинов

\begin{tabular}{|c|c|c|c|c|c|c|}
\hline 17 & Ant3 & & $\downarrow$ & + & 594 & \\
\hline 18 & Ant4 & $4 \mathrm{H}$ или 6Н & $\downarrow$ & + & 595 & \\
\hline 19 & Ant6 & & $\downarrow$ & + & 597 & \\
\hline 20 & Ant7 & & $\downarrow$ & + & & \\
\hline 21 & Ant8 & & $\downarrow$ & + & & \\
\hline 22 & Ant9 & & $\downarrow$ & + & & \\
\hline 23 & Ant10 & & $\downarrow$ & + & & \\
\hline 24 & Ant11 & & $\downarrow$ & + & & \\
\hline 25 & Ant12 & & $\downarrow$ & + & & \\
\hline 26 & Ant14 & & $\downarrow$ & + & & \\
\hline 27 & Ant15 & & $\downarrow$ & + & & \\
\hline 28 & Ant16 & & $\downarrow$ & + & & \\
\hline 29 & Ant23 & $2 \mathrm{HL}$ или 5HL & $\downarrow$ & + & 746 & Druka et al., 2011 \\
\hline 30 & Ant24 & & $\downarrow$ & + & 747 & \\
\hline
\end{tabular}

Примечание. $\uparrow$ и - повышение и понижение содержания соединения; ТФ - транскрипционный фактор Note. $\uparrow$ and $\downarrow$ mean increasing and decreasing of the content of compound; TF - transcription factor 
Таблица 2. Коммерческие пивоваренные сорта ячменя, созданные на основе беспроантоцианидиновых мутантов

Table 2. Commercial barley varieties for brewing obtained based on proanthocyanidin-free mutants

\begin{tabular}{|c|c|c|c|c|}
\hline Сорт & Родословная & $\begin{array}{l}\text { Год } \\
\text { создания }\end{array}$ & Организация & Источник литературы \\
\hline Caminant & ant28.484 (Grit) × Blenheim & 1994 & $\begin{array}{l}\text { Seet Plantbreeding (Хорсенс, } \\
\text { Дания) }\end{array}$ & von Wettstein, 1995, 2007 \\
\hline Clarity & & 1993 & $\begin{array}{l}\text { CRISP Malting Group (Норфолк, } \\
\text { Англия) }\end{array}$ & $\begin{array}{l}\text { CLARITY. } \\
\text { Proanthocyanidin-free } \\
\text { malt, } 1999\end{array}$ \\
\hline Galant & ant17.148 (Triumph)* & 1985 & $\begin{array}{l}\text { Carlsberg Laboratory (Копенгаген, } \\
\text { Дания) }\end{array}$ & van Harten, 1998 \\
\hline Gant & ant499 $\times$ Alexis* & 1997 & $\begin{array}{l}\text { Seet Plantbreeding (Хорсенс, } \\
\text { Дания) }\end{array}$ & Theuer, 2001 \\
\hline NFC 8808 & ant27.488 (Zenit) $\times$ Sewa $\times$ Fergie & 1994 & $\begin{array}{l}\text { Seet Plantbreeding (Хорсенс, } \\
\text { Дания) }\end{array}$ & von Wettstein, 1995 \\
\hline Prominant & Caminant $\times$ Vintage & 1999 & $\begin{array}{l}\text { Seet Plantbreeding (Хорсенс, } \\
\text { Дания) }\end{array}$ & $\begin{array}{l}\text { Briggs et al., 2004; } \\
\text { Ingvordsen, } 2014\end{array}$ \\
\hline Radiant & ant29.667 (Harrington) $\times$ Baronesse & 2003 & $\begin{array}{l}\text { Washington State University } \\
\text { Agricultural Research Center } \\
\text { and the Idaho and Oregon AESs } \\
\text { and USDA-ARS (СШA) }\end{array}$ & von Wettstein et al., 2004 \\
\hline Yeongbaekchal & Radiant $\times$ Saechalssal & 2013 & $\begin{array}{l}\text { National Institute Crop Science, } \\
\text { RDA (Ванджу, Республика Корея) }\end{array}$ & Lee et al., 2016 \\
\hline
\end{tabular}

* по данным NordGen (https://www.nordgen.org/bgs/index.php)

Taketa, 2015a).

Кроме структурных генов, кодирующих ферменты биосинтеза, также идентифицированы локусы, мутации в которых произошли в регуляторных генах, кодирующих транскрипционные факторы. Среди них: Ant2, кодирующий bHLH-подобный регуляторный фактор, определяет синтез антоцианов в вегетативных органах, таких как ости, лемма, листовые влагалища, ушки листового влагалища (Cockram et al., 2010); Ant1, кодирующий МҮВ-подобный транскрипционный фактор, контролирует антоциановую окраску основания растения (Himi, Taketa, 2015b; Shoeva et al., 2015; Zakhrabekova et al., 2015).

Единственный выделенный к настоящему моменту регуляторный ген, специфически контролирующий накопление проантоцианидинов в зерновках ячменя, - Ant28 - кодирует MYB-подобный транскрипционный фактор (Himi et al., 2012). Молекулярные функции для остальных двадцати пяти Antлокусов до сих пор не установлены (см. табл. 1).

\section{Использование мутантов}

\section{для селекции пивоваренных сортов ячменя}

В начале 1970-х гг. в лаборатории Carlsberg начата селекционная программа по созданию беспроантоцианидиновых пивоваренных сортов ячменя. С использованием классического селекционного подхода скрещивания и отбора мутантные аллели генов синтеза проантоцианидинов пере- несены от доноров в коммерческие сорта (табл. 2). Сравнительные исследования линий с мутациями, одновременно нарушающими синтез антоцианов и проантоцианидинов, несмотря на высокие показатели коллоидной стабильности приготовленного из них пива, показали их неэффективность в качестве доноров из-за снижения урожайности полученных сортов и вкусовых качеств получаемого пива. Потери в урожайности мутантных линий по сравнению с родительским сортами составляли до 20-25\%, как, например, в случае мутантной линии ant13.13, полученной на основе сорта Foma. Авторы предположили, что наблюдаемое снижение урожайности обусловлено повышенной чувствительностью линии ant13.13 к мучнистой poce (von Wettstein et al., 1977). Также низкой продуктивностью обладал сорт Galant, полученный в 1985 г. на основе мутанта ant17.148 сорта Triumph (van Harten, 1998). Однако оценка качества солода высокопродуктивных рекомбинантных линий, полученных на основе мутантов ant13 и ant17, продемонстрировала, что некоторые из них имели показатели экстрактивности, вязкости, содержания азота и число Кольбаха на уровне исходных сортов (von Wettstein et al., 1985).

Японские исследователи на основе линии ant13.347 и пивоваренного сорта Haruna Nijo разработали селекционную линию Mokkei 92-130. Пиво, сваренное из Mokkei 92-130, показало превосходную коллоидную стабильность, однако в процессе хранения быстро теряло вкусовые характеристики, что может быть связано со снижением содержания 
полифенольных соединений, обладающих антиоксидантными свойствами, и, как следствие, быстрым окислением ответственных за вкус компонентов пива (Fukuda et al., 1999).

Неудачные попытки использовать в селекции мутанты, у которых мутации затрагивали гены основного пути биосинтеза флавоноидов, объясняются важностью этих соединений в росте и развитии растений (Dixon et al., 2005). Чтобы минимизировать негативные последствия от таких мутаций, разработчики беспроантоцианидиновых сортов решили применять линии, в которых мутации затрагивали последние этапы синтеза проантоцианидинов, тогда как синтез других групп флавоноидных соединений, включая антоцианы, не менялся либо изменялся незначительно. На основе некоторых этих мутантов получены высокоурожайные сорта, успешно прошедшие полевые испытания и тестирования органолептических качеств и коллоидной стабильности.

Так, в 1994 г. в Дании зарегистрированы сорта NFC8808 [ant27.488 (Zenit) $\times$ Sewa $\times$ Fergie] и Caminant [ant28.484 (Grit) $\times$ Blenheim] - оба созданы на основе мутаций в локусах, специфических для синтеза проантоцианидинов. Урожайность сорта Caminant в 1991-1994 гг. превосходила стандарт на 4\%. Полученный сорт не уступал распространенному в те годы в Европе пивоваренному сорту Alexis по качественным характеристикам зерна, солода и сусла, таким как индекс прорастания, экстрактивность, цвет сусла, содержание азота, диастатическая сила и содержание $\beta$-глюканов. Стойкость пива, сваренного из Caminant, была выше, чем стойкость, достигнутая с помощью технологических приемов (применение поливинилпирролидона на этапе фильтрации пива). Пиво, сваренное из NFC8808 и Caminant, не отличалось по вкусовым характеристикам и органолептическим свойствам от пива, сваренного из традиционных пивоваренных сортов ячменя, а также беспроантоцианидиновых сортов, но с добавлением индивидуальных проантоцианидинов и их различных комбинаций. Сделан важный вывод о том, что проантоцианидины не влияют на вкус пива (Delcour et al., 1984). NFC8808 и Caminant выращивали в промышленных масштабах для получения солода и производства пива на пивоварнях Carlsberg (von Wettstein, 2007)

Помимо Дании беспроантоцианидиновые сорта ячменя активно разрабатывали и тестировали в Великобритании. В сотрудничестве с лабораторией Carlsberg там создан высокопродуктивный качественный пивоваренный сорт Clarity (1999), который показал хорошую урожайность при выращивании в восточных областях страны. Испытания пилотных партий пива, приготовленных из этого сорта, показали его преимущества в сравнении с пивом, выполненным из традиционных сортов ячменя, по таким признакам, как пониженное содержание полифенолов и высокая коллоидная стабильность при хранении. Также продемонстрирована возможность использования более высоких температур $\left(+4{ }^{\circ} \mathrm{C}\right.$ по сравнению $\left.\mathrm{c}-1{ }^{\circ} \mathrm{C}\right)$ для стабилизации готового пива. Однако распространения этот сорт не получил, поскольку имел пониженную экстрактивность ${ }^{1}$. По коммерческим

1 CLARITY. Proanthocyanidin-free malt. 1999. CRISP Malting Group.
Доступно: https://www.yumpu.com/en/document/read/4110511/ соображениям авторы не обозначили мутантную линию, на основе которой выведен сорт Clarity, однако указанное в описании сорта наличие антоциановой пигментации на ушках и стебле 2 подразумевает, что этот сорт был создан на основе линии с мутацией в гене, специфичном для синтеза проантоцианидинов.

Еще один сорт на основе беспроантоцианидиновых мутантов - Radiant [ant29.667 (Harrington) $\times$ Baronesse] - создан в США в 2003 г. Помимо коллоидной стабильности, высокой урожайности, устойчивости к патогенным микроорганизмам сорт имел улучшенные пищевые характеристики: каши, приготовленные на его основе, имели светлый (не серый) цвет, что делает этот сорт привлекательным для использования не только в пивоваренной, но и пищевой промышленности (von Wettstein et al., 2004). На основе Radiant в Республике Корея выведен голозерный сорт пищевого назначения Yeongbaekchal [Radiant $\times$ Saechalssal] (Lee et al., 2016).

Создание беспроаноцианидиновых пивоваренных сортов ячменя возможно на основе мутантов с нарушенным синтезом флавоноидных соединений. Однако из-за плейотропного эффекта мутантные аллели большинства генов синтеза флавоноидов не могут быть использованы в селекции таких сортов, поскольку приводят к снижению урожайности и качественных характеристик солода и готового пива. Наиболее удачным оказался опыт использования в селекции беспроаноцианидиновых сортов мутантов, у которых мутации произошли в генах, контролирующих заключительные этапы синтеза проантоцианидинов, и которые, таким образом, оказывают наименьшее влияние на физиологические процессы, протекающие в организме растений.

\section{Заключение}

Анализ мирового опыта указывает на возможность улучшить пивоваренные сорта ячменя с помощью снижения содержания проантоцианидинов в зерне с использованием селекционно-генетических методов. Такой подход позволяет увеличить сроки хранения готового пива за счет повышения его коллоидной стабильности без применения дополнительных технологических приемов. Хотя созданные в прошлом столетии беспроантоцианидиновые сорта ячменя не получили широкого распространения среди крупных производителей, по-видимому, ввиду высокой стандартизации способа производства и ассортимента, сегодня такие сорта могут быть успешно использованы в ремесленном (крафтовом) пивоварении, характеризующемся высокой гибкостью ассортимента продукции, способностью быстро учитывать меняющиеся пожелания клиентов, а также новаторством и экспериментаторством.

\section{Список литературы / References}

Бриттон Г. Биохимия природных пигментов. Москва: Изд-во «Мир», 1986.

[Britton G. Biochemistry of natural pigments. Moscow: Mir Publ., 1986. (in Russian)]

Главачек Ф., Лхотский А. Пивоварение. Москва: Изд-во «Пищевая промышленность», 1977.

clarity-brewers-supply-group

2 Clarity. Spring barley. 1998. Scottish Barley Variety Database.

Доступно: https://barley.agricrops.org/varieties/view/Clarity 
[Glavachek F., Lkhotskiy A. Brewing. Moscow: Food Industry Publ., 1977. (in Russian)]

Кобелев К.В., Данилян А.В., Селина И.В., Созинова М.С. Система оценки пивоваренных свойств селекционного ячменя. Пиво и напитки. 2015;2:40-42.

[Kobelev K.V., Danilyan A.V., Selina I.V., Sozinova M.S. The evaluation system of brewing properties of barley breeding. Pivo i Napitki=Bee and Beverage. 2015;2:40-42. (in Russian)]

Aastrup S., Outtrup H., Erdal K. Location of the proanthocyanidins in the barley grain. Carlsberg Res. Commun. 1984;49:105-109. DOI 10.1007/ BF02913969.

Aron P.M., Kennedy J.A. Flavan-3-ols: nature, occurrence and biological activity. Mol. Nutr. Food Res. 2008;52:79-104. DOI 10.1002/ mnfr.200700137.

Asano K., Ohtsu K., Shinagawa K., Hashimoto N. Affinity of proanthocyanidins and their oxidation products for haze-forming proteins of beer and the formation of chill haze. Agric. Biol. Chem 1984:48(5):1139-1146. DOI 10.1080/00021369.1984.10866300.

Asano K., Shinagawa K., Hashimoto N. Characterization of haze-forming proteins of beer and their roles in chill haze formation. J. Am. Soc Brew. Chem. 1982;40:147-154. DOI 10.1094/ASBCJ-40-0147.

Briggs D.E., Boulton C.A., Brookes P.A., Stevens R. Brewing science and practice. England: Woodhead Publishing Limited, 2004.

Cockram J., White J., Zuluaga D.L., Smit D., Comadran J., Macaulay M. Luo Z., Kearsey M.J., Werner P., Harrap D., Tapsell C., Liu H., Hedley P.E., Stein N., Schulte D., Steuernagel B., Marshall D.F., Thomas W.T.B., Ramsay L., Mackay I., Balding D.J., AGOUEB Consortium; Waugh R., O'Sullivan D.M. Genome-wide association mapping to candidate polymorphism resolution in the unsequenced barley genome. Proc. Natl. Acad. Sci. USA. 2010;107:21611-21616. DOI 10.1073/ pnas.1010179107.

Delcour J.A., Vandenberghe M.M., Dondeyne P., Schrevens E.L., Wijnhoven J., Moerman E. Flavour and haze stability differences in unhopped and hopped all malt Pilsner beers brewed with proanthocyanidin-free and with regular malt. J. Inst. Brew. 1984;90:67-72. DOI 10.1002/j.2050-0416.1984.tb04239.x.

Dixon R.A., Sarnala S. Proanthocyanidin biosynthesis - a matter of protection. Plant Physiology. 2020;184:579-591. DOI 10.1104/ pp.20.00973.

Dixon R.A., Xie D.-Y., Sharma S.B. Proanthocyanidins - a final frontier in flavonoid research? New Phytol. 2005;165:9-28. DOI 10.1111/j.14698137.2004.01217.x.

Druka A., Franckowiak J., Lundqvist U., Bonar N., Alexander J., Hous ton K., Radovic S., Shahinnia F., Vendramin V., Morgante M. Stein N., Waugh R. Genetic dissection of barley morphology and development. Plant Physiol. 2011;155:617-627. DOI 10.1104/ pp.110.166249.

Druka A., Kudrna D., Rostoks N., Brueggeman R., von Wettstein D., Kleinhofs $A$. Chalcone isomerase gene from rice (Oryza sativa) and barley (Hordeum vulgare): physical, genetic and mutation mapping. Gene. 2003;302:171-178. DOI 10.1016/S0378-1119(02)01105-8.

Fukuda K., Saito W., Arai S., Aida Y. Production of a novel proanthocyanidin-free barley line with high quality. J. Inst. Brew. 1999;105(3):179 183. DOI 10.1002/j.2050-0416.1999.tb00017.x.

Himi E., Taketa S. Barley Ant17, encoding flavanone 3-hydroxylase (F3H), is a promising target locus for attaining anthocyanin/proanthocyanidin-free plants without pleiotropic reduction of grain dormancy. Genome. 2015a;58:43-53. DOI 10.1139/gen-2014-0189.

Himi E., Taketa S. Isolation of candidate genes for the barley Ant1 and wheat Rc genes controlling anthocyanin pigmentation in different vegetative tissues. Mol. Genet. Genomics. 2015b;290:1287-1298. DOI 10.1007/s00438-015-0991-0.

Himi E., Yamashita Y., Haruyama N., Yanagisawa T., Maekawa M., Taketa S. Ant28 gene for proanthocyanidin synthesis encoding the R2R3 MYB domain protein (Hvmyb10) highly affects grain dormancy in barley. Euphytica. 2012;188:141-151. DOI 10.1007/s10681-011-0552-5.

Ingvordsen K. Climate change effects to plant ecosystems - genetic resources for future barley breeding. PhD thesis. Technical University of Denmark (DTU), Denmark. 2014.

Jende-Strid B. Genetic control of flavonoid biosynthesis in barley. Hereditas. 1993;119:187-204. DOI 10.1111/j.1601-5223.1993.00187.x.

Jende-Strid B. Mutations affecting flavonoid synthesis in barley. Carls- berg Res. Commun. 1978;43:265-273. DOI 10.1007/BF02906553.

Kristensen $\mathrm{H}$., Aastrup S. A non-destructive screening method for proanthocyanidin-free barley mutants. Carlsberg Res. Commun. 1986:51:509-513. DOI 10.1007/BF02906893.

Kristiansen K.N., Rohde W. Structure of the Hordeum vulgare gene encoding dihydroflavonol-4-reductase and molecular analysis of ant18 mutants blocked in flavonoid synthesis. Mol. Gen. Genet. 1991;230:49-59. DOI 10.1007/BF00290650.

Lamkin W.M., Miller B.S. Note on the use of sodium hydroxide to distinguish red wheats from white common, club, and durum cultivars. Cereal Chem. 1980;57:293-294.

Lee M.-J., Kim Y.-K., Kim K.-H., Seo W.-D., Kang H.-J., Park J.-C., Hyun J-nae, Park K.-H. Quality characteristics and development of naked waxy barley (Hordeum vulgare L.) cultivar "Yeongbaekchal" without discoloration of cooked barley. Korean J. Breed. Sci. 2016;48(4):529-534. DOI 10.9787/KJBS.2016.48.4.529.

Lundqvist U. Scandinavian mutation research in barley - a historical review. Hereditas. 2014;151:123-131. DOI 10.1111/hrd2.00077.

Meldgaard M. Expression of chalcone synthase, dihydroflavonol reductase, and flavanone 3-hydroxylase in mutants in barley deficient in anthocyanin and proanthocyanidin biosynthesis. Theor. Appl. Genet. 1992;83:695-706. DOI 10.1007/BF00226687.

Nordkvist E., Salomonsson A.-C., Åman P. Distribution of insoluble bound phenolic acids in barley grain. J. Sci. Food Agri. 1984;35:657661. DOI 10.1002/jsfa.2740350611.

Shoeva O.Y., Kukoeva T.V., Börner A., Khlestkina E.K. Barley Ant1 is a homolog of maize $C 1$ and its product is part of the regulatory machinery governing anthocyanin synthesis in the leaf sheath. Plant Breed. 2015;134:400-405. DOI 10.1111/pbr.12277.

Shoeva O.Y., Mock H.-P., Kukoeva T.V., Börner A., Khlestkina E.K. Regu lation of the flavonoid biosynthesis pathway genes in purple and black grains of Hordeum vulgare. PloS ONE. 2016;11(10):e0163e782. DOI 10.1371/journal.pone.0163782.

Siebert K.J. Effects of protein-polyphenol interactions on beverage haze, stabilization, and analysis. J. Agric. Food Chem. 1999;47(2):353362. DOI 10.1021/jf980703o.

Siebert K.J., Lynn P.Y. Comparison of polyphenol interactions with polyvinylpolypyrrolidone and haze-active protein. J. Am. Soc. Brew. Chem 1998;56(1):24-31. DOI 10.1094/ASBCJ-56-0024.

Steiner E., Becker T., Gastl M. Turbidity and haze formation in beer - insights and overview. J. Inst. Brew. 2010;116(4):360-368. DOI 10.1002/ j.2050-0416.2010.tb00787.x.

Steiner E., Gastl M., Becker T. Protein changes during malting and brewing with focus on haze and foam formation: a review. Eur. Food Res. Technol. 2011;232:191-204. DOI 10.1007/s00217-010-1412-6.

Theuer R.C. Proanthocyanidin-free barley food composition fortified with iron and methods of making and using. Patent USOO6274179B1. Aug. 14, 2001.

van Harten A.M. Mutation breeding: theory and practical applications. Cambridge: Cambridge University Press, 1998.

Venturelli S., Burkard M., Biendl M., Lauer U.M., Frank J., Busch C. Prenylated chalcones and flavonoids for the prevention and treatment of cancer. Nutrition. 2016;32(11-12):1171-1178. DOI 10.1016/j.nut.2016.03.020.

von Wettstein D. Breeding of value added barley by mutation and protein engineering. Induced mutations and molecular techniques for crop improvement. Proceedings of a symposium. Vienna. 1995;67-76.

von Wettstein D. From analysis of mutants to genetic engineering. Annu. Rev. Plant Biol. 2007;58:1-19. DOI 10.1146/annurev.arplant.58.032806.104003.

von Wettstein D., Cochran J.S., Ullrich S.E., Kannangara C.G., Jitkov V.A., Burns J.W., Reisenauer P.E., Chen X., Jones B.L. Registration of 'Radiant' barley. Crop Science. 2004;44:1859-1860. DOI 10.2135/cropsci2004.1859.

von Wettstein D., Jende-Strid B., Ahrenst-Larsen B., Sorensen J.A. Biochemical mutant in barley renders chemical stabilization of beer superfluous. Carlsberg Res. Commun. 1977;42:341-351. DOI 10.1007/ BF02906119.

von Wettstein D., Nilan R.A., Ahrenst-Larsen B., Erdal K., Ingversen J., Jende-Strid B., Kristiansen K.N., Larsen J., Outtrup H., Ullrich S.E. Proanthocyanidin-free barley for brewing: progress in breeding for high yield and research tool in polyphenol chemistry. Technical Quarterly of the Master Brewers' Association of America. 1985;22:41-52. 
Wannenmacher J., Gastl M., Becker T. Phenolic substances in beer: struc tural diversity, reactive potential and relevance for brewing process and beer quality. Compr. Rev. Food Sci. Food Saf. 2018;17:953-988. DOI 10.1111/1541-4337.12352.

Winkel-Shirley B. Flavonoid biosynthesis. A colorful model for genetics, biochemistry, cell biology, and biotechnology. Plant Physiol. 2001;126:485-493. DOI 10.1104/pp.126.2.485.

Zakhrabekova S., Dockter C., Ahmann K., Braumann I., Gough S.P. Wendt T., Lundqvist U., Mascher M., Stein N., Hansson M. Genetic linkage facilitates cloning of Ert- $m$ regulating plant architecture in barley and identified a strong candidate of Ant1 involved in anthocyanin biosynthesis. Plant Mol. Biol. 2015;88:609-626. DOI 10.1007/ s11103-015-0350-x.

Zimmermann B.F., Galensa R. One for all-all for one: Proof of authenticity and tracing of foods with flavonoids - analysis of proanthocyanidins in barley and malt. Eur. Food Res. Technol. 2007;224(3):385-393. DOI 10.1007/s00217-006-0333-x.

Конфликт интересов. Автор заявляет об отсутствии конфликта интересов.

Поступила в редакцию 13.01.2021. После доработки 08.02.2021. Принята к публикации 09.02.2021. 